\title{
Engineering of Farmer Partnership Model Through Accounting Approach
}

\author{
Eka Ardiansyah ${ }^{1}$, Ahmad Rifa' $^{2}{ }^{2}$, Prayitno Basuki ${ }^{3}$ \\ Faculty of Economy and Business of Mataram University, Indonesia ${ }^{1,2,3}$
}

eka1225@gmail.com ${ }^{1}$

\begin{abstract}
This research was conducted to determine the supply chain conditions carried out by onion farmer groups in Bima Regency. Further, this research also used as the evaluation tool so that it can design and improve supply chain management, especially those relate to institutional readiness of partners in utilizing information technology. The research approach used in this research is qualitative research. Bogdan and Taylor [1] define qualitative methodology as a research procedure that produces descriptive data in the form of written or oral words from people and observable behavior. This research produces an institutional model that utilizes information systems in the management process, so that supply chains that are too long can be more efficient and effective.
\end{abstract}

Keywords : Supply Chain, Accounting System Information, Management Accounting, Red Onion, Marketing Efficiency.

\section{Introduction}

According to Law Number 13 of 2010 concerning Horticulture aspect, Horticulture is a stretch of distribution of horticulture businesses which are united by certain binding factors, both natural, socio-cultural and physical infrastructure factors. Priority and superior commodities in horticulture agribusiness area development program refer to the criteria of market share, competitive advantage, economic value, distribution of production areas and suitability of agro-eco-systems. Nationally, prioritized horticultural commodities are: bananas, mangoes, mangosteen, oranges, durians, potatoes, red peppers, red onions, orchids, chrysanthemums and rhizomes. In horticultural agribusiness area development program, specific commodity determination will be taken through participatory rural appraisal (PRA) ${ }^{1}$ and rapid rural appraisal (RRA) ${ }^{2}$. One of the business activities in "regional development" is the structuring of the supply chain whichfocuses on developing innovative technologies. Problems that occur in the field in the process of developing innovative horticultural technology in Indonesia are generally carried out through direct introduction to users. One disadvantage is that there is no binding obligation from the government to maintain the continuity of technology adoption. Therefore, the development of innovative horticultural technology needs to be built through a more comprehensive partnership. It aims to encourage the development of innovation technology that has several advantages, namely the delineation of the roles of each party involved, integrated use of resources, and fair and balanced commitment. The definition is further elaborated by the Directorate General of Horticulture: 
"Horticultural agribusiness area is a geographical space that has ecosystem similarity and is united by the same infrastructure facilities so as to form an area that contains various horticulturebased business activities including the provision of production facilities, cultivation, handling and processing of post-harvest, marketing, and various supporting activities".[2]

${ }^{1}$ Paticipatory Rural Aappraisal (PPA) is a method of approach in the process of empowerment and increasing community participation, which stresses on community involvement in overall development activities.

${ }^{2}$ RRA (Rapid Rural Appraisal) is a method of assessing village conditions quickly, which in practice, RRA activities are mostly carried out by "outsiders" with little or no involvement of the local community.

The concept of "region" is the most appropriate approach in regional economic development. At present, regional development is increasingly being applied in various developing countries, this is naturally happening considering the development of "regions" can improve regional economic performance in order to build community welfare through sustainable use of resources. In addition, the "regional" economic development policy also uses the concept of economic growth that implements communal relations, economic activities and the environment in harmony.

In the development, despite the positive assumption that coordination between various parties involved in achieving the target of developing horticultural agribusiness areas has been done well, this has not been able to answer supply chain problems from Gapoktan which have an impact on farmer exchange rates (NTP) ${ }^{3}$. These problems can be overcome by improving several aspects: (1) Management Aspects especially those relating to supply chains (2) Information aspects, especially those related to the process of accounting information in the process of distribution of farmer groups (3) financial aspectsespecially those related to financing processes and the purchase of both the private sector and the government through the institution appointed to the farmer, and (4) aspects of social behavior, especially the farmer groups, which are related to habits in the preparation of a cost allocation plan for each hectare of land managed.

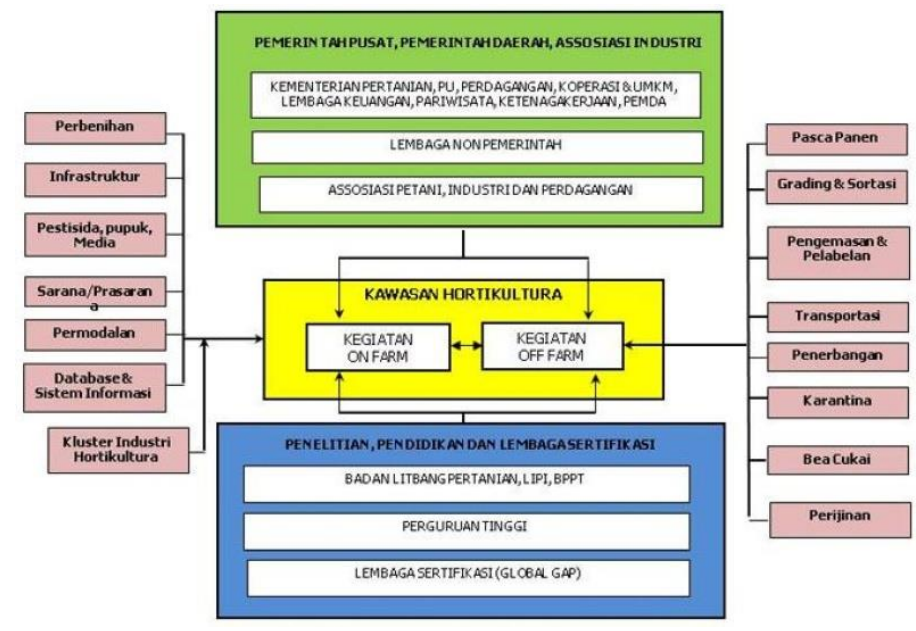

Source: Agriculture Ministry 
By reconstructing the functions and responsibilities of farmer groups in utilizing the existing information technology, it is hoped that a model of a farmer-oriented farmer group will be built and able to bridge the needs of farmers, especially in the process of financing and marketing of shallots. This is only able to be attempted by remodeling existing farmer groups to maximize managerial and accounting functions by utilizing information technology that is currently developing.

\section{Research Methodology}

In accordance with the objectives, this study belongs to the type of exploratory research. Exploratory is a study conducted to understand the nature of research problems well. Lack of understanding of the nature of research problems as a result of the limited research that has been done on the phenomena that want to be understood (Sekaran, 2003). Likewise with the limited research that has been carried out regarding institutional strengthening related to the development of farmer group partnerships. Thus, exploratory research is sufficient to get a more understanding of the right model in the effort to develop the area through farmer group partnerships.

This qualitative research is specifically directed to the use of case study methods. According to Lincoln and Guba[3] which states that qualitative approaches can also be called case studies or qualitative, namely in-depth and detailed research on everything related to the subject of research. The selection of case studies as a strategy for this research is also because research questions use the words "how and why", and do not require control of behavior and focus on contemporary events. This is in accordance with the criteria, the situation is relevant to the research strategy presented by Yin[4] Case studies are research strategies in which researchers carefully investigate a program, event, activity, process, or group of individuals [5] .

The location of this study is located inBima Regency, which is one of the autonomous regions in the province of West Nusa Tenggara, located at the eastern end of the island of Sumbawa adjacent to the city of Bima (a fragment of Bima District).

${ }^{3}$ Farmer Exchange Rate (NTP) is an index of farmers' purchasing power in financing household needs, which is the ratio of the weighted prices of each commodity received by farmers to the weighted prices of food consumption, non-food consumption, production costs and additional capital goods paid by farmers.)

Geographically, Bima district is at position $117^{\circ} 40^{\prime \prime}-119^{\circ} 10^{\prime \prime}$ east longitude and $70^{\circ} 30$ "south latitude[6] Topographically, the majority of the regencies in Bima (70\%) are mountainous highlands while the rest $(30 \%)$ are plains. About $14 \%$ of the lowland proportion is rice fields and more than half is dry land. The focus of this research is directed at improving supply chains through institutional engineering of farmer groups by utilizing information systems in Bima district, especially in Ngali village. The selection of the focus of this research is to remodel the onion farmer groups that run a horticulture area development program through a partnership pattern that has not been effective. The general focus is to obtain an overview of how local governments interpret the partnership process as part of the welfare process of farmer groups as well as an effort to encourage the modernization of farmer groups by utilizing existing technological developments, more specifically the modernization of farmer group performance that can cut the supply chain efforts to improve the welfare of farmers.

To answer the problems that will be examined, it used a purposive sampling technique to determine the informants. According to Sugiono [7] purposive sampling means that the informants determined by the researchers were people who had the information needed in this study and they were always in touch with the problems being examined. [8] states that purposive sampling is used because the information to be taken comes from sources that are deliberately chosen based on 
predetermined criteria. The instrument used in this study is the researcher himself by placing himself as a participant observer (participant observer). The researcher as a research instrument is intended as a data collection tool. The researcher makes observations and listens carefully to the smallest possible. The position of the researcher is also a planner, executor, data collector, analyst, data interpreter, and ultimately becomes the reporter of the research results[1]

Because a research design is expected to present a series of logical statements, the analysis used in this study uses three relevant tests [4] namely: Construct Validity, External Validity, and Reliability. (1) The techniques used to test construct validity are: (a) by using multiple sources of evidence, by encouraging unified inquiry efforts. (b) by building a series of evidence. (c) ask the key informant to reread the results of the report. (2) For external validity is to establish the domain where the findings of a study can be visualized [4]. Regarding to the findings in this study can be generalized outside of the case under study. In analytic generalizations, the researcher seeks to generalize a series of specific results to a broader theory. (3) Reliability shows that the implementation of a study if using the same technique or procedure will produce the same findings. The purpose of this test is to get confidence if the next researcher follows the same methods and procedures as described by the researcher and holds the same case again, the latter researcher will arrive at the same findings and conclusions [4].

\section{RESULTS AND DISCUSSION}

Based on the results of observations of the conditions of the farmers and the existence of agricultural institutions in Ngalivillage, it found the fact thatthe most of Ngali villagers had not yet conducted business activities in a market-oriented group. The agribusiness activities carried out are still individual. Institutions of farmers such as farmer groups have not seriously sought to collect commodities and products to be marketed together in groups. This assumption arises because sales to middlemen are considered easier and more practical. This can be found from the results of interviews stating:

“... There are many farmer institutions in this village such as farmer group, but it is not use as its function. The institution is only used as tool of requisite of getting subsidy fertilizer

(.....similar to the farmer institution, there are agriculture institutions in this village, but the activities are not purchasing the red onion commodities or others. It only functions as the administration items of subsidy fertilizer proposal.

The condition of supply chain can be identified as follows:

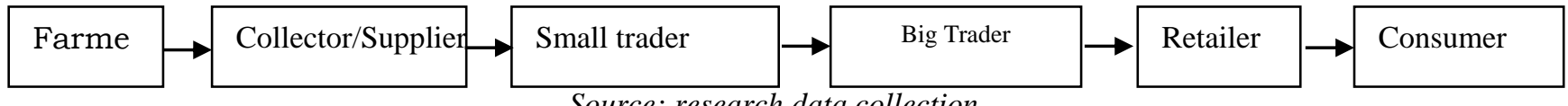

Source: research data collection

In addition, the lack of collective marketing is also due to the lack of enthusiasm and entrepreneurial spirit of the institutional managers of farmers. Partnerships have also not developed because there are trauma factors in the failure of partnerships in the past to have an impact on producing commodities that have not been market oriented. In this regard, to ensure the welfare of farmers and to maintain the purchase price of commodity shallots at the farm level, it is necessary to make a supply chain design that is able to replace the existing supply chain. One of 
the most appropriate models is by utilizing local institutions that exist today. Local institutions can be cooperatives or farmer groups that already exist in Ngali village. Strengthening this local institution must also be accompanied by an increase in managerial capabilities and partnerships built with large traders as partners. This chain modeling is an effort that utilizes technology that will be run as a commodity chain of shallots.

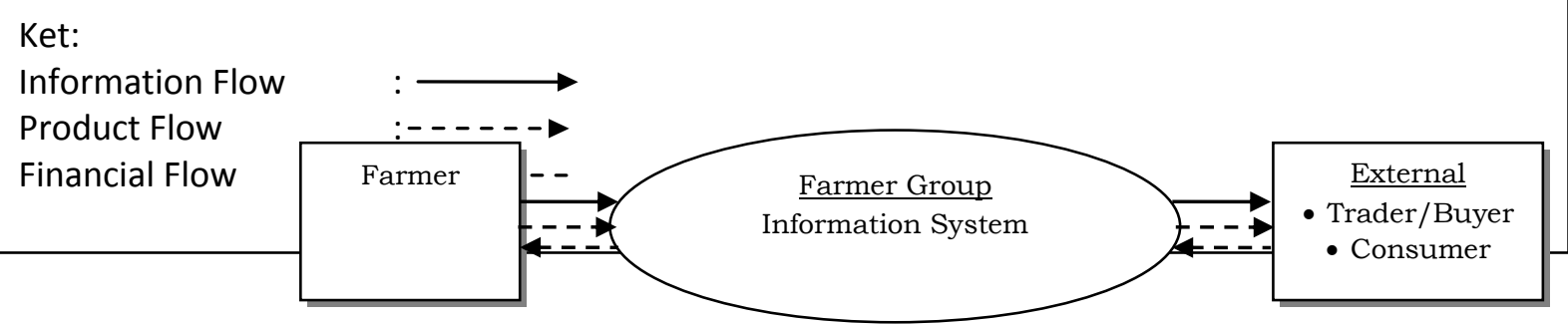

Source: research data collection

After the chain model is created, the next process is the creation of work designs and institutional schemes that are in line with managerial functions. In this stage, a planning master plan was created which functions as a control tool in the formation of a farmer group institutional framework. The master plan framework is also a work reference in research that consists of 3 aspects, namely: (1) Establishment of Institutions, (2) Formation of information flow, and (3) utilization of information systems.

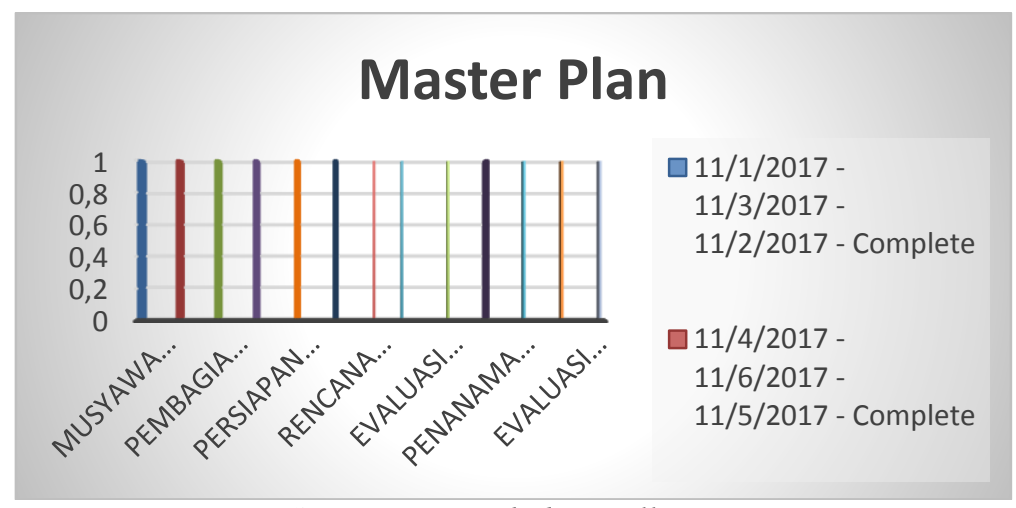

Source: research data collection 


\section{a. Establishment of Institutions}

It has been mentioned earlier that throughout Indonesia, especially in Ngali village, farmer institutions only act as administrative items, where farmers who are members of farmer groups do not have specific functions as part of developing farmer groups oriented to management accounting. This can be understood considering that the current form of farmer groups in Ngali village only consists of a chairman, secretary and treasurer and members consisting of \pm 25 people. So to create a group that is oriented to managerial functions needs to be created a new institutional structure that has a specific division of functions and tasks. This farmer group was then given the name "Kabuju" which was taken from the name of a hamlet in the village of Ngali. In contrast to existing farmer groups, there are additional functions of buying and marketing that are useful as part of the function of purchasing commodity products to farmers and marketing as part of the sales function to traders and end consumers. Both of these parts are additions to treasurer functions but with different delegation of responsibilities so that the financial flow that occurs can make it easier in the process of preparing financial statements for farmer groups. strengthening local institutions to meet national food needs[9] . In addition, Deepak Shah also outlined the importance of strengthening local institutions as micro-economic drivers that can have an impact on improving people's welfare [10].

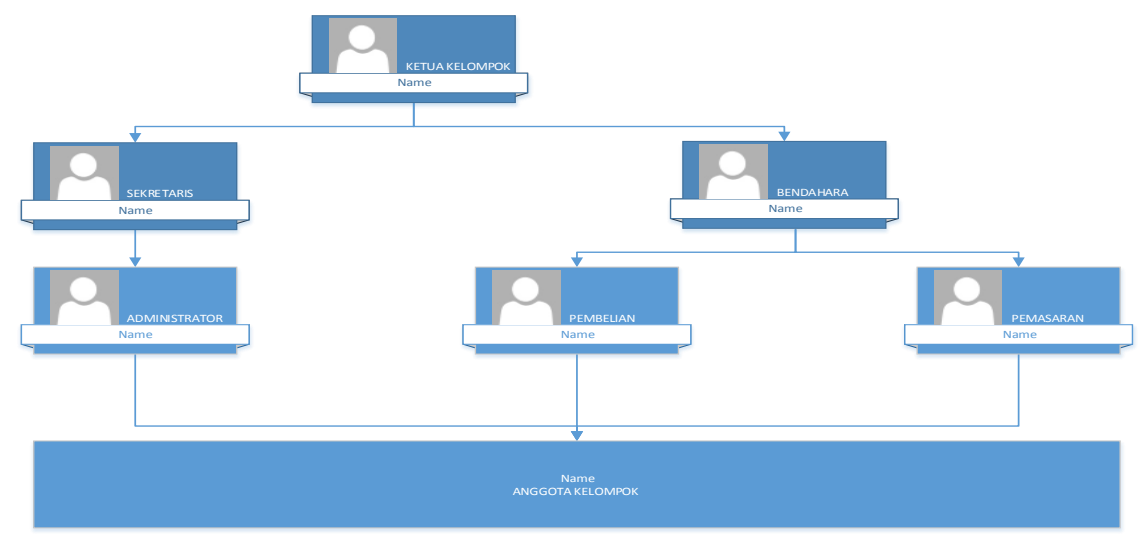

Source: research data collection

\section{b. Information Flow}

After the institutional structure along with the functions and tasks of each field are understood, the next process is to establish the framework and flow of information systems used in 'Kabuju' farmer groups. This process is the initial foundation in designing the flow of information which is expected to correlate with the external needs and information needed to build external cooperation and maintain the supply of shallots from farmers. The importance of this information flow is explained by Jie as an effort to create a competitive advantage in facing business competition[11]

The initial process in the preparation of flow and systematic information that will be carried out is to determine the input and output of the system that you want to develop. (1) Designing input or input, is part of the task of receiving input data that aims to streamline the flow of information in order to achieve high accuracy. (2) Output or output that is useful as a process of both management and accounting reports in the form of performance reports and financial statements. 


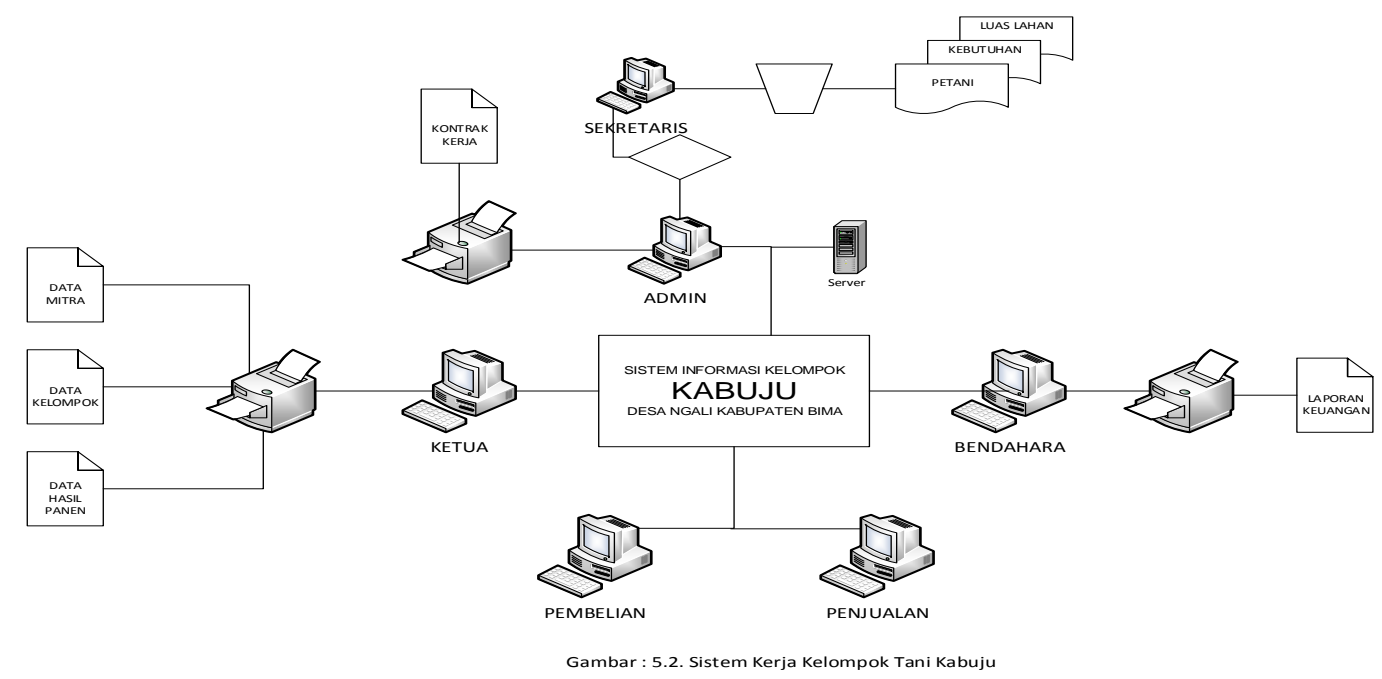

Source: research data collection

\section{c. Making Information Systems}

After the framework of information flow involving farmers and traders is made, the next step is to create an information system that is used and implemented by information and technologybased program applications, the importance of this information system is explained by Surya as an integral part of accounting [12]. The information flow system that will be created in the information system application can be seen in the picture:

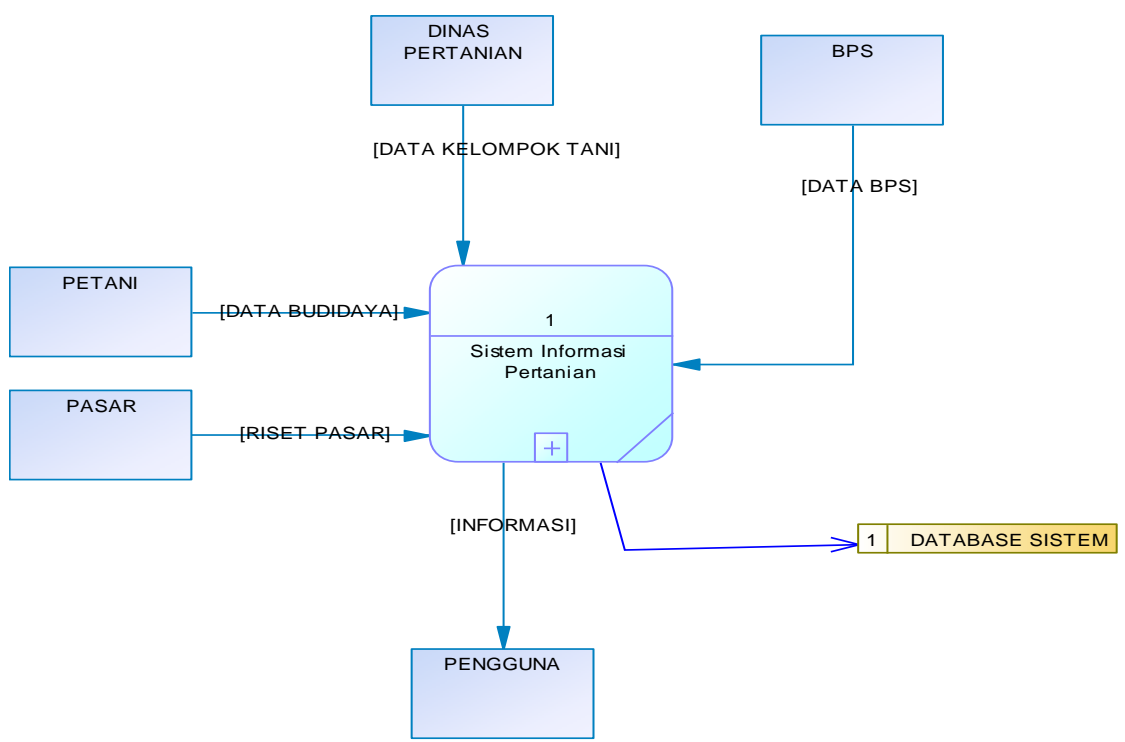

Source: research data collection 
In the process of making the system, the use of information technology is directed as a catalyst in streamlining the flow of information so that "kabuju" farmer groups can use all information as a communication medium, both internally related to the process of purchasing group member harvests, as well as external ones red to traders. Strengthening managerial performance will be useful in the process of financing and purchasing by farmer groups to farmers who are members of farmer groups [13]

\section{Conclusion}

With the case study approach used, it was found that the length of the red onion supply chain in Bima District not only caused the failure of the horticulture development program, but it is also not able to maintain the production of red onion commodity which had implications for increasing farmers' welfare in Ngali village. This condition is compounded by the unpreparedness of agricultural institutions, especially farmer groups in modernizing themselves as part of efforts to strengthen local institutions. Therefore, strengthening local institutions is important. Strengthening local institutions is not only done through the introduction of machinery and technology related to on-farm processing and cultivation of onions but also group managerial strengthening.

In the process of managerial strengthening, the use of information technology was found to be able to effectively information and data used in coordination at the internal level of farmer groups. Modernization of farmer groups through the use of technology can cut the length of the red onion supply chain in Ngali village, besides that it can also provide solutions in the process of preparing financial reports and planning the allocation of planting costs as a reference in the financing process by external parties. With the 'Kabuju' farmer institution model that has utilized information technology, the application of accounting principles can be done effectively and a more marketoriented management system.

This research only directs one farmer group as an example model, so that it cannot be generalized whether the same model can work for other farmer groups and different commodities. In addition, the use of information technology that is still very simple causes some operations to be done manually.

\section{References}

[1] L. J. Moeloeng, "Metodologi Penelitian Kualitatif (36th ed.).," 2017.

[2] kementan, "Sektor Pertanian Berkontribusi Positif Terhadap Pertumbuhan Ekonomi RI Triwulan II 2017 (Fourth Edi). Sage Puclications,Inc.," 2017.

[3] sayekti, "Penulisan Usulan dan Laporan Penelitian Kualitatif. .," 1992.

[4] R. K. Yin, "Case Study Research and Applications: Design and Methods (Fourt Edit).," 2017.

[5] R. D. Wilson and J. W. Creswell, "Research Design: Qualitative and Quantitative," 1996.

[6] Wikipedia, "Kabupaten Bima. Retrieved from https://id.wikipedia.org/wiki/Kabupaten_Bima," 2016.

[7] Sugiono, "Metode Penelitian Administrasi.," 2008.

[8] U. Sekaran, "Metode Penelitian Untuk Bisnis (Edisi Revi).," 2003.

[9] G. X and M. A, "Chain governance structures: The European traditional food sector. British Food Journal," 2009, pp. 765-775.

[10] D. Shah, "Synthesis of Agribusiness Success Models Under Co-Operative and Private Sector in India. Ssrn, 411004.," 2016.

[11] J. F, P. K A, and C. R J, "Linking supply chain practices to competitive advantage: An example from Australian agribusiness.," 2013.

[12] F. Surya, J. Akuntansi, and P. N. Padang, "Hubungan Pengetahuan Komputer dengan Pemahaman Sistem Informasi Akuntansi.," 2005. 
[13] K. P, "Pembiayaan Dengan Pola Kemitraan.” 